\title{
DNA oxidation profiles of copper phenanthrene chemical nucleases
}

\author{
Zara Molphy ${ }^{1}$, Creina Slator ${ }^{1}$, Chryssostomos Chatgilialoglu ${ }^{2,3}$ and Andrew Kellett ${ }^{1 *}$ \\ ${ }^{1}$ School of Chemical Sciences, National Institute for Cellular Biotechnology, Dublin City University, Dublin, Ireland, ${ }^{2}$ Istituto \\ per la Sintesi Organica e la Fotoreattività, Consiglio Nazionale delle Ricerche, Bologna, Italy, ${ }^{3}$ Institute of Nanoscience and \\ Nanotechnology, National Center for Scientific Research "Demokritos," Athens, Greece
}

\section{OPEN ACCESS}

Edited by:

Youla S. Tsantrizos,

McGill University, Canada

Reviewed by:

Martin Schmeing,

McGill University, Canada

John Brazier,

University of Reading, UK

*Correspondence:

Andrew Kellett,

School of Chemical Sciences,

National Institute for Cellular Biotechnology, Dublin City University,

Glasnevin, Dublin 9, Ireland andrew.kellett@dcu.ie

Specialty section:

This article was submitted to Chemical Biology, a section of the journal Frontiers in Chemistry

Received: 22 January 2015 Accepted: 30 March 2015 Published: 21 April 2015

Citation: Molphy Z, Slator C, Chatgilialoglu C and Kellett $A$ (2015) DNA oxidation profiles of copper phenanthrene chemical nucleases. Front. Chem. 3:28.

doi: 10.3389/fchem.2015.00028
The deleterious effects of metal-catalyzed reactive oxygen species (ROS) in biological systems can be seen in a wide variety of pathological conditions including cancer, cardiovascular disease, aging, and neurodegenerative disorder. On the other hand however, targeted ROS production in the vicinity of nucleic acids - as demonstrated by metal-activated bleomycin-has paved the way for ROS-active chemotherapeutic drug development. Herein we report mechanistic investigations into the oxidative nuclease activity and redox properties of copper(II) developmental therapeutics [Cu(DPQ)(phen)] ${ }^{2+}$ (Cu-DPQ-Phen), [Cu(DPPZ)(phen)] $]^{2+}$ (Cu-DPPZ-Phen), and [\{Cu(phen) $\left.)_{2}\right\}_{2}(\mu$-terph)](terph) (Cu-Terph), with results being compared directly to Sigman's reagent $\left[\mathrm{Cu}(\text { phen })_{2}\right]^{2+}$ throughout (phen $=1,10$-phenanthroline; $\mathrm{DPQ}=$ dipyridoquinoxaline; DPPZ = dipyridophenazine; Terph $=$ terephthalate). Oxidative DNA damage was identified at the minor groove through use of surface bound recognition elements of methyl green, netropsin, and $\left[\mathrm{Co}\left(\mathrm{NH}_{3}\right)_{6}\right] \mathrm{Cl}_{3}$ that functioned to control complex accessibility at selected regions. ROS-specific scavengers and stabilizers were employed to identify the cleavage process, the results of which infer hydrogen peroxide produced metal-hydroxo or free hydroxyl radicals $\left({ }^{\bullet} \mathrm{OH}\right)$ as the predominant species. The extent of DNA damage owing to these radicals was then quantified through 8-oxo2'-deoxyguanosine (8-oxo-dG) lesion detection under ELISA protocol with the overall trend following Cu-DPQ-Phen > Cu-Terph > Cu-Phen > Cu-DPPZ. Finally, the effects of oxidative damage on DNA replication processes were investigated using the polymerase chain reaction (PCR) where amplification of 120 base pair DNA sequences of varying base content were inhibited-particularly along A-T rich chains-through oxidative damage of template strands.

Keywords: copper, phenazine, chemical nuclease, hydroxyl radical, DNA damage, 8-oxo-dG

\section{Introduction}

Oxygen radical generation is an inevitable consequence of aerobic existence and has been implicated in a wide variety of pathological conditions including cancer, cardiovascular disease, aging, and neurodegenerative disease (Cooke and Evans, 2007). Reactive oxygen species (ROS) are created in a variety of endogenous chemical and biological processes in the human body-predominantly through oxygen metabolism. The sequential reduction of molecular oxygen can generate reactive intermediates such as superoxide $\left(\mathrm{O}_{2}^{\circ-}\right)$ and hydrogen peroxide $\left(\mathrm{H}_{2} \mathrm{O}_{2}\right)$ that initiate a cascade of redox reactions toward the production of hydroxyl radicals $(\bullet \mathrm{OH})$ and related metal-oxo species 
(Kellett et al., 2012). Molecular targets of ROS include proteins, lipids, and nucleic acids-the deleterious effects of which include base and deoxyribose modifications that ultimately precipitate single or double strand breaks. To counteract this, the majority of cells possess defense mechanisms such as base excision repair (BER)-e.g., 8-oxoguanine glycosylase (OGG1) (Xu et al., 2014) - and nucleotide excision repair (NER) pathways that prevents genome instability to ultimately limit cytotoxicity, the accumulation of deleterious mutations, and maintain genome integrity. Two major ${ }^{\bullet} \mathrm{OH}$ induced DNA lesions are 8oxoguanine (8-oxo-dG), a mutagenic lesion that induces $\mathrm{G} \rightarrow$ $\mathrm{T}$ transversions widely seen in mutated oncogenes and tumor suppressor genes, and the poorly mutagenic thymine glycol (Basu et al., 1989; Chatgilialoglu and O'Neill, 2001). Recent evidence suggests ${ }^{\bullet} \mathrm{OH}$ attacks occur primarily at base moieties and account for the majority of total hydrogen atom abstraction on DNA alone (Chatgilialoglu et al., 2011). Thus, 8-oxo-dG has been subjected to intensive investigation due to its prominence as a biomarker within ROS-mediated disease pathology, and its ease of detection in bodily fluids and tissue samples has allowed a variety of detection methods to accurately assess 8oxo-dG lesions including high-pressure liquid chromatography (HPLC), gas chromatography (GC), mass spectrometry (MS), and the enzyme linked immunosorbent assay (ELISA).

In addition to the induction of endogenous DNA damage, exogenous sources including UV light, ionizing radiation, environmental agents, pharmaceuticals, and industrial chemicals can also initiate ROS production (Klaunig et al., 2010). Indeed the clinical antineoplastic agent bleomycin (BLM) is a redox active agent capable of DNA oxidative cleavage in the presence of $\mathrm{Fe}$ (II) (and $\mathrm{Cu}(\mathrm{I})$ ), molecular oxygen, and endogenous one electron reductants (Stubbe and Kozarich, 1987; Burger, 1998; Chen et al., 2008). Bleomycin can abstract hydrogen atoms from deoxyribose in the DNA backbone, specifically from $\mathrm{C}^{\prime}$ position (Breen and Murphy, 1995). The active form of Fe(II)-BLM is a ternary, highvalence $\mathrm{Fe}(\mathrm{III})-\mathrm{O} \bullet$ species (Rodriguez and Hecht, 1982; Pratviel and Bernadou, 1989; Gajewski et al., 1991) that undergoes an electron reduction by biological reductants (e.g., $L$-ascorbate) or by another molecule of Fe(II)-BLM (Burger et al., 1981; Natrajan et al., 1990). Fe(II)-BLM can form 8-oxo-dG and other base propenals, however these are known to occur in small amounts; the formation of such DNA degradation products results from
- $\mathrm{OH}$ oxidative damage-a side product only of the ferryl-oxo species-that does not functionally contribute to biological systems or participate in the nuclease activity of activated Fe(II)BLM (Rodriguez and Hecht, 1982).

Our group have recently investigated a range of $\left[\mathrm{Cu}(\text { phen })_{2}\right]^{2+}$ (Cu-Phen) (Phen $=1,10$-phenanthroline) type systems as potential lead compounds for therapeutic and biochemical application (Kellett et al., 2011; Prisecaru et al., 2012, 2013; Molphy et al., 2014). $\left[\mathrm{Cu}(\text { phen })_{2}\right]^{2+}$, originally reported by Sigman et al. (1979), is believed to cleave DNA through a variety of copper bound oxidants including $\mathrm{Cu}^{3+}$ $\mathrm{OH}$ and $\mathrm{Cu}^{+}-\mathrm{OOH}$ with the possibility of free ${ }^{\bullet} \mathrm{OH}$ playing a role in the overall process (Marshall et al., 1981; Johnson and Nazhat, 1987). Recent work on the development of bischelate $\mathrm{Cu}^{2+}$ phenanthroline-phenazine cationic complexes of $[\mathrm{Cu}(\mathrm{DPQ})(\text { phen })]^{2+}(\mathrm{Cu}-\mathrm{DPQ}-\mathrm{Phen})$ and $[\mathrm{Cu}(\mathrm{DPPZ})(\text { phen })]^{2+}$ $(\mathrm{Cu}-\mathrm{DPPZ}-\mathrm{Phen})(\mathrm{DPQ}=$ dipyridoquinoxaline; $\mathrm{DPPZ}=$ dipyridophenazine) have demonstrated how extension of the ligated phenazine ligand influences DNA recognition and oxidative degradation (Molphy et al., 2014). Indeed, when designer phenazine ligands (DPQ and DPPZ) are incorporated into the "copper bis-phen" chemical nuclease model, these agents display enhanced DNA recognition and intercalation among the highest reported on ctDNA (Table $1, K_{\mathrm{app}} \approx 3 \times 10^{7} \mathrm{M}(\mathrm{bp})^{-1}$ ). Since nuclearity is also established as an important factor in oxidative DNA cleavage (Li et al., 2005; van der Steen et al., 2010), we also reported the dinuclear complex, $\left[\left\{\mathrm{Cu}(\mathrm{phen})_{2}\right\}_{2}(\mu\right.$-terph) $]$ (terph) ( $\mathrm{Cu}$-Terph) (terph $=$ terephtalate), which is capable of inducing oxidative DNA strand breaks in the absence of exogenous reductant (Kellett et al., 2011). Cu-Terph has promising in vitro cytoxicity toward human derived breast, prostate, colon, ovarian, and lung human cance cell lines, with comparable activity to mitoxantrone-a clinincal anthracene topoisomerase II inhibitor (Kellett et al., 2011; Prisecaru et al., 2012).

In this contribution we identify, using head-to-head analysis, the comparative oxidative DNA cleavage properties of DNA binding $\mathrm{Cu}^{2+}$ complexes $\mathrm{Cu}-\mathrm{Phen}, \mathrm{Cu}-\mathrm{DPQ}-\mathrm{Phen}, \mathrm{Cu}-\mathrm{DPPZ}$ Phen, and Cu-Terph (Scheme 1) through a variety of biophysical and molecular biological methods. Additionally, we report these agents inhibit DNA polymerase activity-particularly at A$\mathrm{T}$ rich sites - through oxidative degradation of template strands. To that end, we report (i.) oxidative DNA profiles in the presence

TABLE 1 | Summary of DNA binding properties of tested complexes toward calf thymus DNA (ctDNA) along with synthetic nucleic acid polymers poly $\left[\mathrm{d}(\mathrm{A}-\mathrm{T})_{2}\right]$ and poly $\left[\mathrm{d}(\mathrm{G}-\mathrm{C})_{2}\right]$.

\begin{tabular}{|c|c|c|c|c|c|c|}
\hline Compound & $\mathbf{C}_{50}{ }^{a}$ & $K_{\text {app }} M(b p)^{-1 b}$ & $Q(\mu M)$ poly $\left[d(A-T)_{2}\right]^{c}$ & $Q(\mu M) \operatorname{poly}\left[d(G-C)_{2}\right]^{c}$ & $\Delta \mathrm{T}_{M}\left({ }^{\circ} \mathrm{C}\right)$ poly $\left[\mathrm{d}(\mathrm{A}-\mathrm{T})_{2}\right]^{\mathrm{d}}$ & $\Delta \mathrm{T}_{M}\left({ }^{\circ} \mathrm{C}\right)$ poly $\left[\mathrm{d}(\mathrm{G}-\mathrm{C})_{2}\right]^{\mathrm{d}}$ \\
\hline Cu-Phen & 179.21 & $0.67 \times 10^{6}$ & 13.34 & 7.96 & $-0.02 \pm 0.29$ & $06.64 \pm 1.58$ \\
\hline Cu-DPQ-Phen & 3.93 & $30.45 \times 10^{6}$ & 8.34 & 3.97 & $0.60 \pm 0.18$ & $11.39 \pm 1.10$ \\
\hline Cu-DPPZ-Phen & 4.63 & $25.85 \times 10^{6}$ & 11.60 & 10.12 & $0.50 \pm 0.10$ & $10.44 \pm 1.10$ \\
\hline Cu-Terph & 39.36 & $0.30 \times 10^{6}$ & 8.6 & 10.3 & NT & NT \\
\hline
\end{tabular}

${ }^{a} C_{50}=$ concentration required to reduce $50 \%$ fluorescence of saturated bound ethidium bromide (12.6 $\left.\mu \mathrm{M}\right)$ on ctDNA (10 $\left.\mu \mathrm{M}\right)$.

${ }^{b} K_{a p p}=K_{e} \times 12.6 / C_{50}$ where, $K_{e}=9.5 \times 10^{6} \mathrm{M}(\mathrm{bp})^{-1}$ (apparent binding constant on ctDNA).

${ }^{c}$ Fluorescence Quenching $(Q)$ of limited bound Ethidium Bromide $(5 \mu \mathrm{M})$ bound poly $\left[\mathrm{d}(\mathrm{A}-\mathrm{T})_{2}\right]$ and poly $\left[\mathrm{d}(\mathrm{G}-\mathrm{C})_{2}\right]$ by $\mathrm{Cu}^{2+} \mathrm{complexes.}$

${ }^{d} \Delta T_{M}=$ difference in thermal melting $\left(T_{M}\right)$ of drug-treated nucleotide at $r=0.1$ compared with drug-untreated nucleotide.

$N T=$ not tested. 


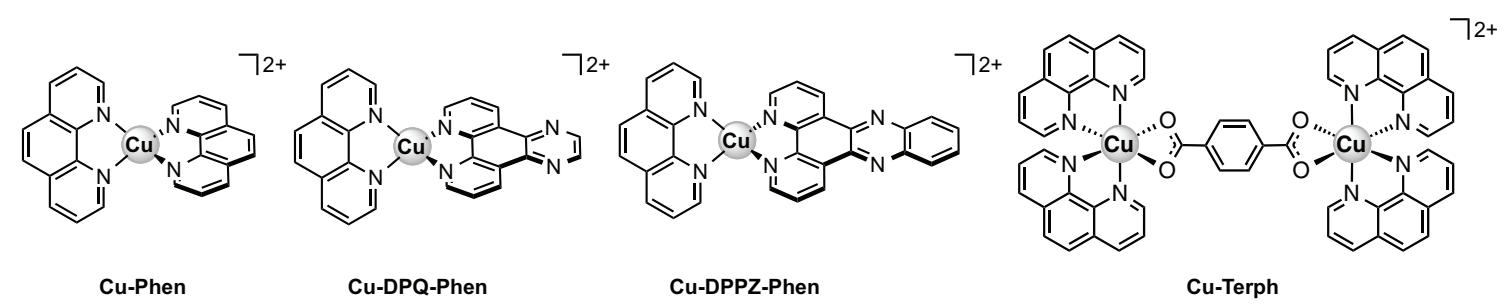

SCHEME 1 | Molecular structures of the copper(II) complex cations examined in this study.

of DNA recognition agents of netropsin, methyl green, and $\left[\mathrm{Co}\left(\mathrm{NH}_{3}\right)_{6}\right] \mathrm{Cl}_{3}$, (ii.) DNA cleavage profiles in the presence of radical trapping and stabilizing co-factors, (iii.) quantitation of 8-oxo-dG lesions arising from complex treated superhelical plasmid DNA, and (iv.) DNA polymerase inhibition on DNA templates of differential A-T content. The DNA binding profiles for this series have previous been reported and are summarized in Table 1 (Kellett et al., 2011; McCann et al., 2013; Prisecaru et al., 2013; Molphy et al., 2014); simple phenanthroline containing complexes (Cu-Phen and $\mathrm{Cu}$-Terph) have moderate binding constants toward ctDNA while phenazine compounds (Cu-DPQ-Phen and Cu-DPPZ-Phen) can be considered as high-affinity dsDNA intercalators. Further, ethidium bromide fluorescence quenching on alternating duplex polymerspoly $\left[\mathrm{d}(\mathrm{A}-\mathrm{T})_{2}\right]$ and poly $\left[\mathrm{d}(\mathrm{G}-\mathrm{C})_{2}\right]$ - has shown complexes intercalate from both minor and major grooves. It has not been established, as yet, if chemical nuclease activity occurs preferentially at either or both recognition sites.

\section{Materials and Methods}

\section{Preparation of the Complexes}

Chemicals were purchased from Sigma-Aldrich Ireland and used without further purification.

DPQ and DPPZ ligands were initially generated through the Schiff base condensation reactions of 1,10 phenanthroline-5,6-dione with ethylenediamine and $o$-phenylenediamine respectively. The bis-phenanthroline complex $\left[\mathrm{Cu}(\text { phen })_{2}\right]\left(\mathrm{NO}_{3}\right)_{2}(\mathrm{Cu}-\mathrm{Phen})$ was prepared by refluxing 1,10-phenanthroline with copper(II) nitrate in a 2:1 molar ratio in aqueous-ethanol (Prisecaru et al., 2013). The phenazine complexes $[\mathrm{Cu}(\mathrm{DPQ})($ Phen $)]\left(\mathrm{NO}_{3}\right)_{2} \quad(\mathrm{Cu}-\mathrm{DPQ}-\mathrm{Phen})$ and $[\mathrm{Cu}(\mathrm{DPPZ})($ Phen $)]\left(\mathrm{NO}_{3}\right)_{2}$ (Cu-DPPZ-Phen) were prepared by treating the mono-phenanthroline complex $[\mathrm{Cu}(\mathrm{Phen})]\left(\mathrm{NO}_{3}\right)_{2}$ with 1 molar equivalent of the corresponding phenazine ligand in ethanol (Molphy et al., 2014). The $\left[\mathrm{Cu}_{2}(\mu\right.$-terephthalate) $(1,10-$ phen $\left.)_{4}\right]^{2+}$ was prepared by ethanolic reflux of copper(II) terephthalate hydrate and 1,10-phenanthroline in a 1:2 ratio according to the reported method (Kellett et al., 2011).

\section{DNA Cleavage Studies}

\section{DNA Cleavage in the Presence of Added Reductant}

The ability of the complexes to oxidatively damage DNA in the presence of added reductant was determined using a method previously published by this laboratory with minor changes (Molphy et al., 2014). Reactions were carried out according to the following general procedure: in a total volume of $20 \mu \mathrm{L}$ using $80 \mathrm{mM}$ HEPES buffer ( $\mathrm{pH} 7.2$ ) with $25 \mathrm{mM} \mathrm{NaCl}, 1 \mathrm{mM} \mathrm{Na}$-L-ascorbate, $400 \mathrm{ng}$ superhelical pUC19 (NEB, N3041) and varying concentrations of test complex $(250 \mathrm{nM}, 500 \mathrm{nM}, 1 \mu \mathrm{M}$ and $2.5 \mu \mathrm{M})$. Complexes were initially prepared in DMF and further diluted in HEPES buffer (Fisher). Samples were incubated at $37^{\circ} \mathrm{C}$ for $30 \mathrm{~min}$. Reactions were quenched by adding $6 \times$ loading buffer (Fermentas) containing $10 \mathrm{mM}$ Tris- $\mathrm{HCl}, 0.03 \%$ bromophenol blue, $0.03 \%$ xylene cyanole FF, $60 \%$ glycerol, $60 \mathrm{mM}$ EDTA and samples were loaded onto an agarose gel (1.2\%) containing $8 \mu \mathrm{L}$ EtBr. Electrophoresis was completed at $70 \mathrm{~V}$ for $2 \mathrm{~h}$ in $1 \times$ TAE buffer.

\section{DNA Cleavage in the Presence of Non-Covalently Bound Recognition Elements}

This protocol was adapted from a previously reported procedure (Tabassum et al., 2012). Briefly, 400 ng pUC19 was incubated with $25 \mathrm{mM} \mathrm{NaCl}, 1 \mathrm{mM} \mathrm{Na}$-L-ascorbate, and 8 , or $16 \mu \mathrm{M}$ of either methyl green, netropsin or hexamine cobalt(III) chloride in $80 \mathrm{mM}$ HEPES buffer ( $\mathrm{pH} 7.2$ ) for $45 \mathrm{~min}$ at $37^{\circ} \mathrm{C}$. Sample tubes were then vortexed and varying concentrations of test complex were added $(250 \mathrm{nM}, 500 \mathrm{nM}, 1 \mu \mathrm{M}$, and $2.5 \mu \mathrm{M})$. The reaction mixture was further incubated at $37^{\circ} \mathrm{C}$ for $30 \mathrm{~min}$. The reaction was then quenched with $6 \times$ loading buffer and subjected to gel electrophoresis (prepared and stained as previously described).

\section{DNA Oxidation with ROS Scavengers and Stabilizers}

The presence of ROS specific scavengers was used to determine the effect on the DNA cleavage abilities of each copper complex. The procedure was adapted to the previously reported method (Zhou et al., 2014). Briefly, to a final volume of $20 \mu \mathrm{L}, 80 \mathrm{mM}$ HEPES ( $\mathrm{pH}=7.2$ ), $25 \mathrm{mM} \mathrm{NaCl}, 1 \mathrm{mM} \mathrm{Na}$-L-ascorbate, and $400 \mathrm{ng}$ of pUC19 DNA were treated with drug concentrations of $250 \mathrm{nM}, 500 \mathrm{nM}, 1 \mu \mathrm{M}$, and $2.5 \mu \mathrm{M}$ in the presence ROS scavengers / stablilisers; KI (10 mM), $\mathrm{NaN}_{3}(10 \mathrm{mM})$, DMSO (10\%), and $\mathrm{D}_{2} \mathrm{O}(77 \%)$. Reactions were incubated for $30 \mathrm{~min}$ at $37^{\circ} \mathrm{C}$, quenched with DNA loading dye and loaded onto $1.2 \%$ agarose gel and run under conditions previously described.

\section{HT Quantitation of 8-oxo-dG}

Quantitation of 8-oxo-dG lesions present in $3000 \mathrm{ng}$ pUC19 plasmid DNA pre-incubated with test complexes $(10$ and $20 \mu \mathrm{M})$ at $37^{\circ} \mathrm{C}$ for $30 \mathrm{~min}$ was achieved utilizing a high throughput 
8-oxo-dG ELISA kit (Trevigen) and performed as per manufacturers guidelines. Samples of damaged DNA were examined in triplicate using a 96 well plate, pre-coated with 8-oxo-dG along with varying concentrations of a standard 8-oxo-dG (200, 100, $50,25,12.5,6.25$, and $3.13 \mathrm{nM}$ ). An 8-oxo-dG monoclonal antibody, which competitively binds to 8-oxo-dG immobilized to each well, was added to the plate with excess antibody being washed with PBST $(1 \times$ PBS, $0.1 \%$ Tween 20$)$. The concentration of 8-oxo-dG was determined based on antibody retention in each well using goat anti-mouse IgG-HRP conjugated antibody and colorimetric detection substrate TACS-Sapphire. Product formation was inversely proportional to 8 -oxo-dG present in the DNA sample. Samples were determined using a Bio-Tek synergy HT multimode microplate reader at $450 \mathrm{~nm}$ and quantitation of 8-oxo-dG was extrapolated from the standard curve.

\section{PCR Inhibition Studies}

This protocol was adapted from a previously reported procedure (Sanchez-Cano et al., 2010). 400 ng pUC19 DNA was initially exposed to each test complex in the presence and absence of $1 \mathrm{mM}$ added reductant at $37^{\circ} \mathrm{C}$ for $30 \mathrm{~min}$ (Figures S-2, S-3). $20 \mathrm{ng}$ of damaged DNA template was removed and PCR reactions (35 cycles) were carried out with each varying G-C content primer set (Figure S-4) at optimum annealing temperatures and analyzed using gel electrophoresis. This investigation was replicated in the absence of added reductant (Figure S-5) and also at lower drug loading $(250 \mathrm{nM}, 500 \mathrm{nM}, 1 \mu \mathrm{M}$, and $2.5 \mu \mathrm{M})$ with $1 \mathrm{mM}$ reductant (Figure S-6).

\section{Results and Discussion}

\section{DNA Cleavage in the Presence of Non-Covalently Bound Recognition Elements}

We have previously shown that DNA oxidative cleavage by copper complexes is dependent on a range of factors including (but not limited to): plasmid DNA conformation and type, presence of competing metal chelating agents (e.g.,

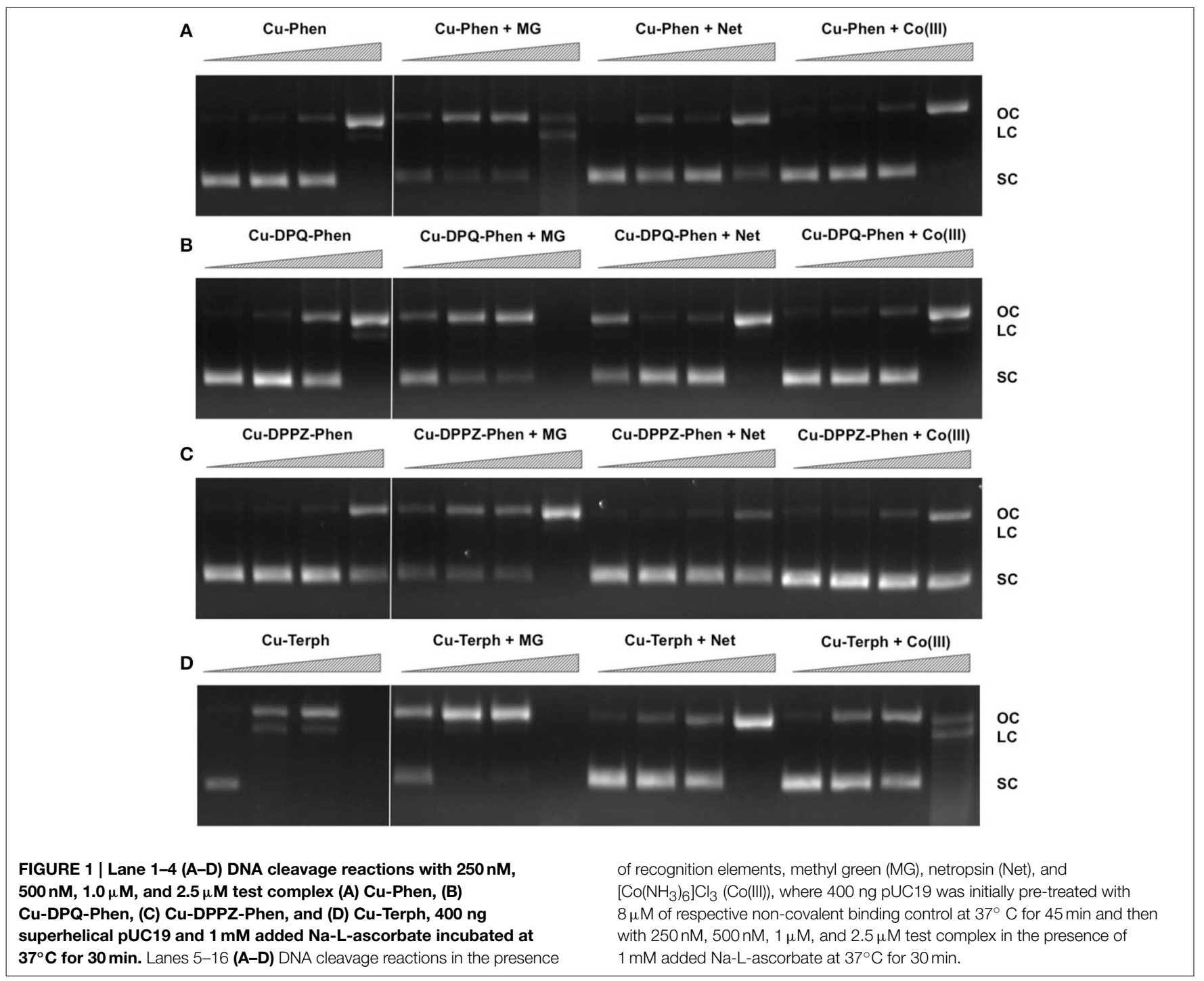


EDTA), reaction/exposure time, and presence/concentration of exogenous reductant or oxidant. In the current work we examine chemical nuclease activity of supercoiled pUC19 plasmid DNA in the presence of $1 \mathrm{mM}$ reductant (Na-L-ascorbate) using agarose gel electrophoresis. In order to ensure the copper(I) active species (i.e., the nuclease) was fully generated, each complex was initially reduced with $1 \mathrm{mM}$ of added reductant prior to pUC19 titration. Relaxation of supercoiled (SC, FI) pUC19 DNA into open circular (OC, FII) and linear (LC, FIII) conformations was employed to qualitatively measure the cleavage efficiency of complexes over a concentration range of $250 \mathrm{nM}, 500 \mathrm{nM}, 1.0 \mu \mathrm{M}$, and $2.5 \mu \mathrm{M}$ for $30 \mathrm{~min}$ at $37^{\circ} \mathrm{C}$ (Figures 1A-D, lanes 1-4). Complexes show concentration-dependent relaxation of FI (superhelical) to FII (open circular/nicked), while FIII (linear conformation) is evident at $2.5 \mu \mathrm{M}$ Cu-DPQ-Phen exposure and with $500 \mathrm{nM}$ of the dinuclear agent $\mathrm{Cu}$-Terph. Complete digestion of SC DNA occurs only with the maximum tested concentration $(2.5 \mu \mathrm{M})$ of $\mathrm{Cu}$-Terph. The overall trend in chemical nuclease activity is $\mathrm{Cu}$-Terph $>$ Cu-DPQ-Phen $>$ Cu-Phen $>$ Cu-DPPZ-Phen. The activity profiles observed here are in good agreement with those previously reported by this group; $\mathrm{Cu}$-Terph has previously displayed nicking at $1.0 \mu \mathrm{M}$ on the plasmid pBR322 with complete digestion occurring thereafter (Prisecaru et al., 2012). We also established that both 2.5 and $5.0 \mu \mathrm{M}$ of $\mathrm{Cu}$-Phen induced nicking (OC) on both pBR322 (Prisecaru et al., 2012; McCann et al., 2013) with activity being impeded in the presence of EDTA (Prisecaru et al., 2013). The nuclease activity of both $\mathrm{Cu}-\mathrm{DPQ}-\mathrm{Phen}$ and $\mathrm{Cu}-$ DPPZ-Phen has been identified previously (Molphy et al., 2014), however, direct analysis with the current conditions cannot be made.

In an attempt to determine DNA cleavage site specificity, minor groove (netropsin, Net) and major groove (methyl green, MG) binders, along a surface electrostatic binding and condensing agent $\left(\left[\mathrm{Co}\left(\mathrm{NH}_{3}\right)_{6}\right] \mathrm{Cl}_{3}, \mathrm{Co}(\mathrm{III})\right)$ were pre-incubated with pUC19 DNA prior to the addition of test complex (Figures 1A-D, lanes 5-16). In all cases, presence of the major groove binder MG enhanced chemical nuclease activity with greater nicking (OC) and linearization (LC) frequency compared with control experiments. Conversely, the minor groove binder Net impedes chemical nuclease activity as pUC19 is clearly protected from both OC and LC damage across all experiments. The cationic surface binding agent $\left[\mathrm{Co}\left(\mathrm{NH}_{3}\right)_{6}\right]^{3+}$ had no major impact on the chemical nuclease activity of $\mathrm{Cu}-\mathrm{Phen}$

TABLE 2 | Scavengers and stabilizers utilized within this study.

\begin{tabular}{lll}
\hline Scavenger $^{\mathbf{a}}$ Stabilizer $^{\mathbf{b}}$ & ROS & References \\
\hline $\mathrm{NaN}_{3}{ }^{\mathrm{a}}$ & ${ }^{1} \mathrm{O}_{2}$ & Franco et al., 2007 \\
$\mathrm{Kl}^{\mathrm{a}}$ & $\mathrm{H}_{2} \mathrm{O}_{2}$ & Dunand et al., 2007; Steffens et al., 2012 \\
$\mathrm{DMSO}^{\mathrm{a}}$ & $\bullet \mathrm{OH}$ & Franco et al., 2007; Mazzer et al., 2007 \\
$\mathrm{D}_{2} \mathrm{O}^{\mathrm{b}}$ & ${ }^{1} \mathrm{O}_{2}$ & Merkel et al., 1972; Xia et al., 2006
\end{tabular}

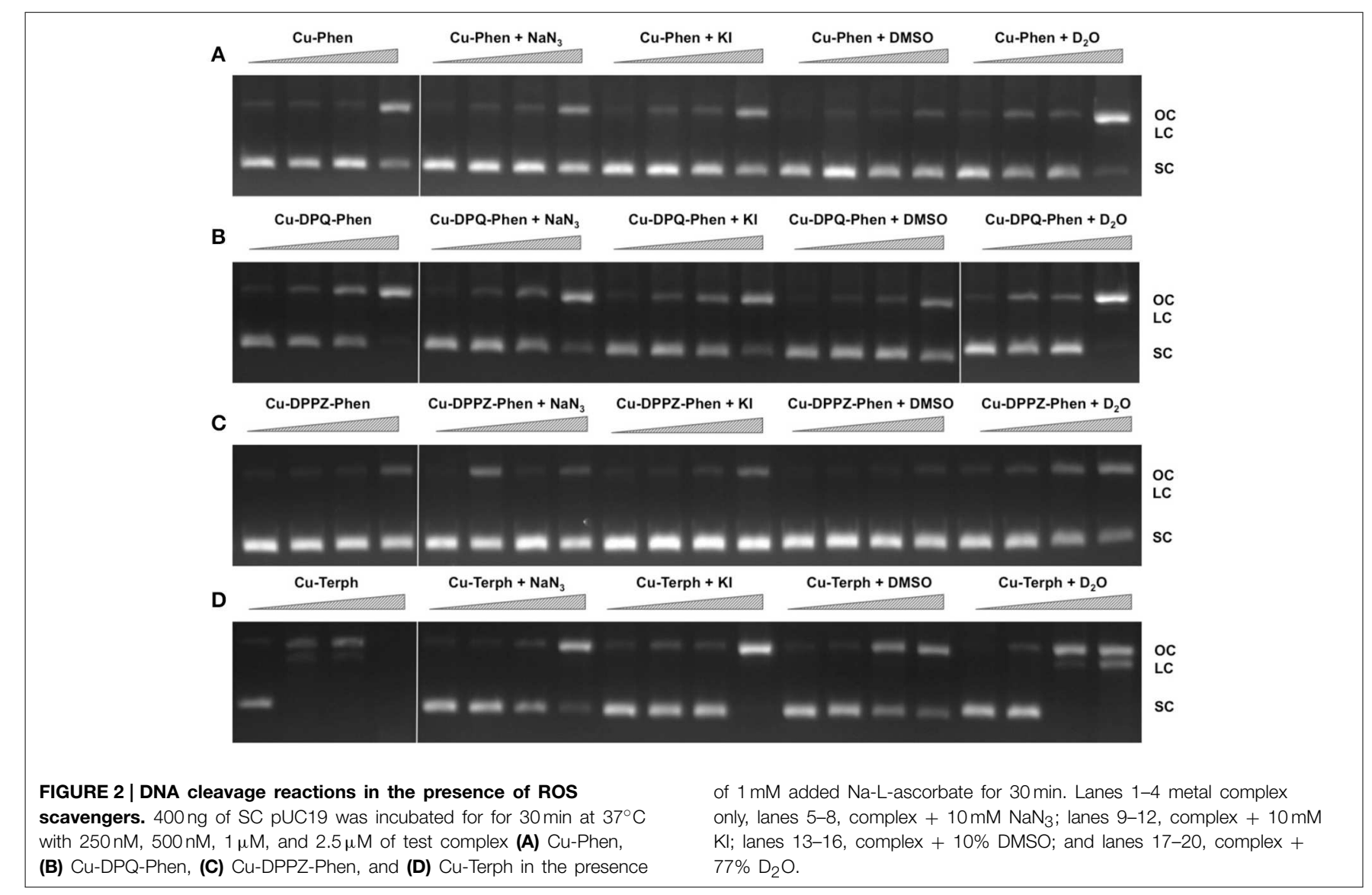


and $\mathrm{Cu}-\mathrm{DPPZ}$-Phen but did reduce nicking by $\mathrm{Cu}-\mathrm{DPQ}$-Phen at $1 \mu \mathrm{M}$ and was also effective in protecting pUC19 damage by $\mathrm{Cu}-$ Terph. Taken together, evidence here points toward the minor groove as the major site of DNA oxidation by this complex series; MG bound pUC19 primes the minor groove for chemical nuclease activity while titrated Net clearly diminishes this damage. Indeed this observation of minor groove targeting is consistent with previous analysis on the rapid cleavage of poly (dA-dT) by 2:1 phenanthroline- $\mathrm{Cu}^{+}$mixtures (Sigman et al., 1979).

\section{DNA Oxidation with ROS Scavengers and Stabilizers}

In order to examine ROS species involved in DNA oxidation, activity was investigated in the presence of radical-specific scavengers and stabilizers (Table 2) with results shown in Figure 2. Before complex analysis, scavengers were confirmed to have no impact on pUC19 conformation (data not shown). Control experiments are in excellent agreement with those observed in Figure 1 (lanes 1-4), however, a fraction of superhelical (FI)
pUC19 was found to remain upon $2.5 \mu \mathrm{M}$ exposure of $\mathrm{Cu}$ Phen. Results here suggest that ${ }^{\bullet} \mathrm{OH}$ is the most prevalent radical species involved in strand scission as the presence of DMSO considerably impedes cleavage activity of all complexes. It is noteworthy DMSO had a major impact on cleavage activity of $\mathrm{Cu}$-Terph as only the maximum tested concentrations (1.0 and $2.5 \mu \mathrm{M})$ contained nicked cleavage products. The presence of the $\mathrm{H}_{2} \mathrm{O}_{2}$ scavenger, $\mathrm{KI}$, was also found to inhibit chemical nuclease activity of tested complexes-again most notably within $\mathrm{Cu}$ Terph reactions-and this observation is consistent with previous trapping studies conducted on these model systems (Johnson and Nazhat, 1987; Prisecaru et al., 2013). It is interesting to note the catalase enzyme is a more effective scavenger of $\mathrm{H}_{2} \mathrm{O}_{2}$ compared with $\mathrm{KI}$ as previous work revealed complete inhibition of DNA oxidation by $\mathrm{Cu}-\mathrm{Phen}, \mathrm{Cu}-\mathrm{DPQ}-\mathrm{Phen}$, and Cu-DPPZ-Phen complexes (Molphy et al., 2014).

The role of ${ }^{1} \mathrm{O}_{2}$ was next examined utilizing the $\mathrm{NaN}_{3}$ scavenger (Franco et al., 2007) and $\mathrm{D}_{2} \mathrm{O}$ as a ${ }^{1} \mathrm{O}_{2}$ stabilizer (Merkel et al., 1972; Xia et al., 2006). Nuclease activity by<smiles>Nc1nc2c([nH]c(=O)n2C2CC(O)C(CO)O2)c(=O)[nH]1</smiles>

8-oxo-dG

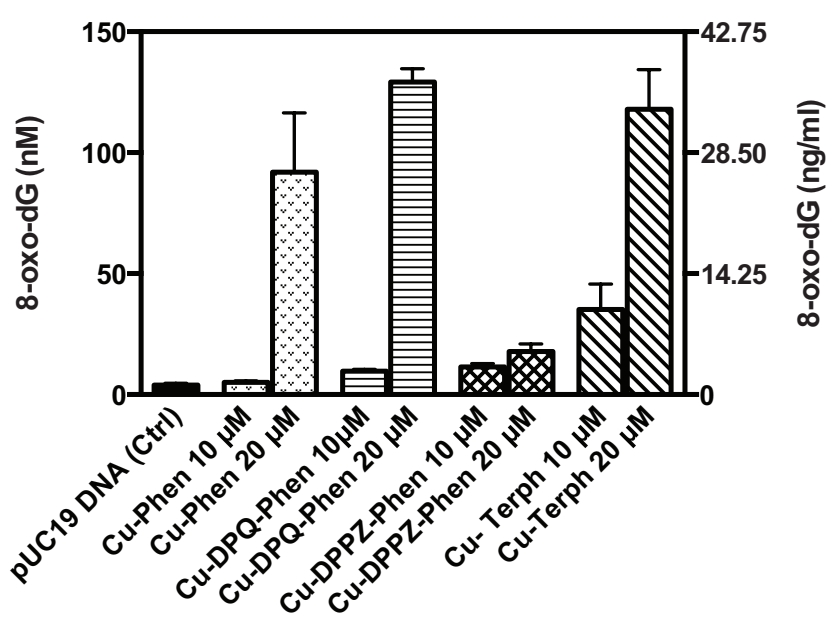

FIGURE 3 | Structure and quantification of 8-oxo-dG. Graph represents level of generated 8-oxo-dG as nM (left axis) and $\mathrm{ng} / \mathrm{mL}$ (right axis). $3000 \mathrm{ng}$ of SC pUC19 with 10 and $20 \mu \mathrm{M}$ of test complexes
Cu-Phen, Cu-DPQ-Phen, Cu-DPPZ-Phen, and Cu-Terph with $1 \mathrm{mM}$ $\mathrm{Na}$-L-ascorbate were incubated at $37^{\circ} \mathrm{C}$ for $30 \mathrm{~min}$ and followed by ELISA protocol.

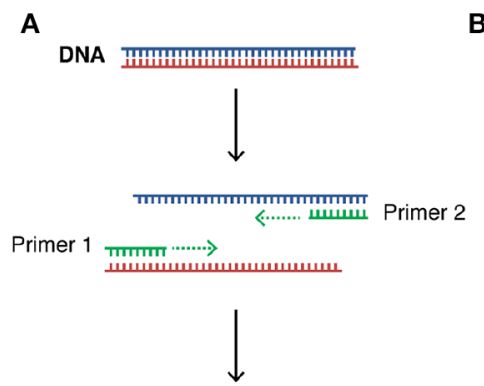

PCR Amplification

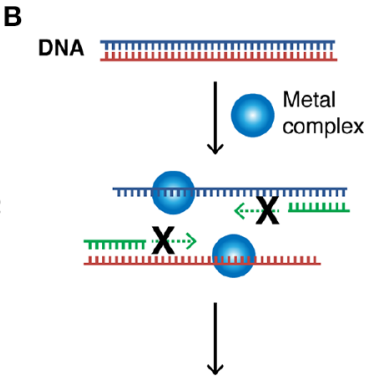

PCR Inhibition

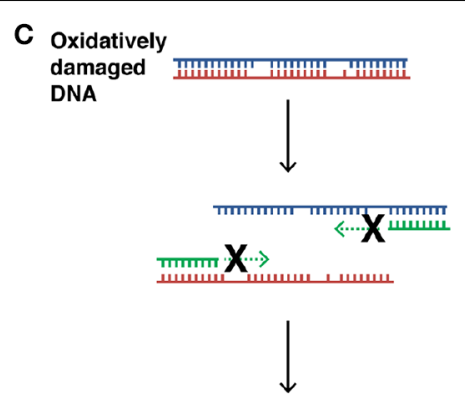

PCR Inhibition
FIGURE 4 | (A) Illustration of steps involved in a successful PCR reaction (denaturation, primer annealing, primer extension, and template amplification), (B) the impact of a bound metal complex as physical block of the primer extension step, (C) inhibition of DNA amplification in the PCR cycle through the oxidative damage of template strand. 
$\mathrm{Cu}-\mathrm{Phen}, \mathrm{Cu}-\mathrm{DPQ}-\mathrm{Phen}$, and Cu-DPPZ-Phen complexes was only marginally inhibited by $\mathrm{NaN}_{3}$ while no change in activity (relative to control) was observed in $\mathrm{D}_{2} \mathrm{O}$ thus suggesting a limited role in DNA oxidation by ${ }^{1} \mathrm{O}_{2}$. NaN $\mathrm{NaN}_{3}$ did, however, impede activity by $\mathrm{Cu}$-Terph but the role of ${ }^{1} \mathrm{O}_{2}$ in the scission process could not be verified as $\mathrm{D}_{2} \mathrm{O}$ was also found to reduce activity, somewhat.

\section{Quantitation of 8-oxo-dG}

To examine if the oxidative DNA lesion, 8-oxo-dG, is formed during complex reactions with DNA, an HT 8-oxo-dG ELISA kit was employed for immunological detection and quantification. The complex series was investigated at 10 and $20 \mu \mathrm{M}$ with 3000 ng of SC pUC19, with 8-oxo-dG being quantified in both nM and $\mathrm{ng} / \mathrm{mL}$ (Figure 3). Nuclease activity was firstly confirmed at $10 \mu \mathrm{M}$ and $20 \mu \mathrm{M}$ (Figure S-1). Low numbers of lesions were detected in the untreated control $(3.92 \pm 0.79 \mathrm{nM})$ and the exposure of pUC19 to each of the complexes at $10 \mu \mathrm{M}$ resulted in detectable increases in 8-oxo-dG (between 35.24 and $5.05 \mathrm{nM}$ ) with the trend following $\mathrm{Cu}$-Terph $>\mathrm{Cu}$-DPPZ-Phen $>\mathrm{Cu}-$ DPQ-Phen $>\mathrm{Cu}$-Phen. Upon $20 \mu \mathrm{M}$ complex exposure significant levels of 8-oxo-dG (between 129.22 and $17.77 \mathrm{nM}$ ) were produced with the trend changing toward $\mathrm{Cu}-\mathrm{DPQ}-\mathrm{Phen}>\mathrm{Cu}$ Terph $>\mathrm{Cu}$-Phen $>\mathrm{Cu}$-DPPZ-Phen. Given the ${ }^{\bullet} \mathrm{OH}$ radical is fundamental in the production of 8-oxo-dG, results here demonstrate DNA oxidation by copper phenanthrene complexes, particularly under extensive shearing conditions (Figure S-1), drive formation of 8-oxo-dG lesions.

\section{PCR Inhibition Studies}

Our next aim was to investigate how oxidative lesions-induced through complex exposure-can ultimately impact on in vitro
DNA processing by the polymerase chain reaction (PCR) (Figure 4). During the normal PCR process, a DNA template is initially denatured through heating to more than $90^{\circ} \mathrm{C}$ to separate double stranded DNA into constituent single strands. The second step involves lowering the temperature $\left(40-60^{\circ} \mathrm{C}\right)$ to allow specifically designed forward and reverse primers to anneal at targeted regions (for selective amplification) through complementary base pairing. At this point the temperature is increased again to allow Taq polymerase to attach at each priming site and extend to synthesize a new DNA strand. This thermal cycling process allows for a chain reaction to occur in which the selected DNA template is exponentially amplified creating millions of copies of the targeted sequence (Figure 4A). In our study $400 \mathrm{ng}$ of pUC19 plasmid DNA was initially exposed to increasing concentrations $(2.5,5,10,20,30,40$, and $50 \mu \mathrm{M})$ of test complexes in the absence and presence of exogenous reductant at $37^{\circ} \mathrm{C}$ for $30 \mathrm{~min}$ and used as a substrate for the PCR reaction along with specific primer sets to generate three 120 bp sequences of varying G.C content $(35,50$, and $63 \%$ ). PCR inhibition (up to $50 \mu \mathrm{M}$ ) was not achieved by any tested agent (Figure S-5) in the absence of added reductant indicating physical blocking of the PCR process (Figure 4B) does not occur. With added reductant, however, the pattern emerges as described in Figure 4C. In the high A.T amplification set (35\% G.C), PCR was inhibited by $5.0 \mu \mathrm{M}$ of the mono-nuclear complexes ( $\mathrm{Cu}-\mathrm{Phen}, \mathrm{Cu}-\mathrm{DPQ}-\mathrm{Phen}$ and $\mathrm{Cu}-$ DPPZ-Phen). In the case of the di-nuclear agent ( $\mathrm{Cu}$-Terph), complete inhibition of template amplification was observed at all exposure levels (Figure 5A). Within the 50 and 63\% G.C templates (Figures 5B,C respectively), the PCR reaction was impeded at 5.0 $\mu \mathrm{M}$ for both $\mathrm{Cu}-\mathrm{DPQ}-\mathrm{Phen}$ and $\mathrm{Cu}$-Terph complexes whereas template DNA, oxidatively damaged by $5.0 \mu \mathrm{M}$

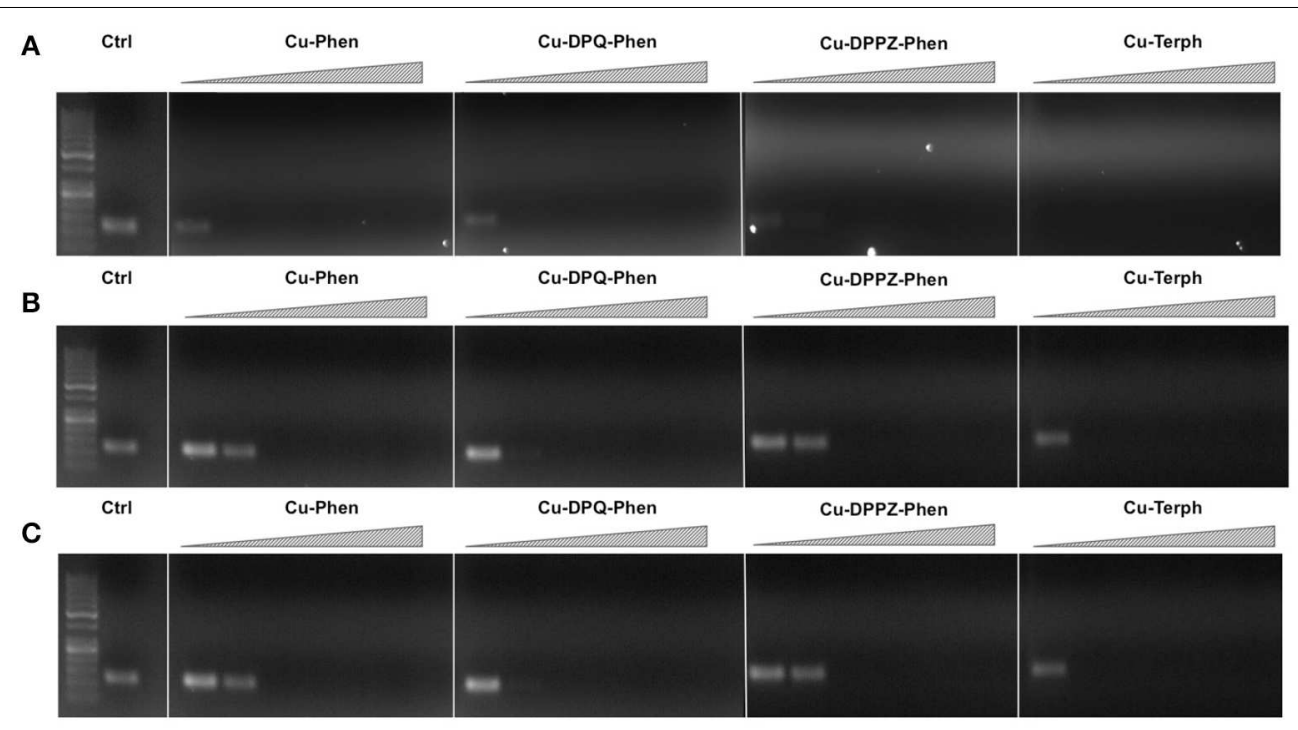

FIGURE 5 | 400 ng pUC19 DNA was initially exposed to $2.5,5,10,20$, 30,40 , and $50 \mu \mathrm{M}$ of each test complex in the presence of $1 \mathrm{mM}$ added reductant at $37^{\circ} \mathbf{C}$ for $30 \mathrm{~min}$. $20 \mathrm{ng}$ of damaged DNA template was removed and PCR reaction was carried out with each varying GC content primer set at optimum annealing temperatures and analyzed using gel electrophoresis. Panel (A) Lane 1, 50 bp DNA ladder, lane 2, 35 \% GC control; lane 3-9, 35\% GC + Cu-Phen; lane 10-16, 35\% GC + Cu-DPQ-Phen; lane 17-23, 35\% GC + Cu-DPPZ-Phen and lane 24-30, $35 \% \mathrm{GC}+\mathrm{Cu}$-Terph. Panel (B) 50\% GC, and Panel (C) 63\% GC respectively. All duplex sequences generated were 120 base pairs. 
of $\mathrm{Cu}$-Phen and $\mathrm{Cu}$-DPPZ-Phen, was still suitable for amplifying 120 base pair DNA sequences.

\section{Conclusions}

Mechanistic investigations into oxidative cleavage properties of the copper(II) complex series $\left[\mathrm{Cu}(\text { phen })_{2}\right]^{2+}(\mathrm{Cu}-\mathrm{Phen})$ $[\mathrm{Cu}(\mathrm{DPQ})(\text { phen })]^{2+}$ (Cu-DPQ-Phen), [Cu(DPPZ)(phen) $]^{2+}$ (Cu-DPPZ-Phen), and $\left[\left\{\mathrm{Cu}(\text { phen })_{2}\right\}_{2}(\mu\right.$-terph $\left.)\right]($ terph $) \quad(\mathrm{Cu}-$ Terph) reveal chemical nuclease activity occurs primarily at the minor groove; titration of the major groove binder, methyl green, enhances DNA degradation-most likely by directing (priming) complex-DNA interactions to the minor groove-while the presence of the minor grove binder, netropsin, was found to significantly reduce oxidative damage on pUC19. It is also interesting to note that no correlation exists between chemical nuclease activity (Figure 1) and apparent DNA binding constant (Table 1). Instead, nuclearity has a more dramatic effect as evidenced by $\mathrm{Cu}$-Terph mediated DNA damage. ROS-specific scavengers employed to identify the cleavage mechanism revealed metal-hydroxo or free hydroxyl radicals $\left(\bullet^{\bullet} \mathrm{OH}\right)$, and not ${ }^{1} \mathrm{O}_{2}$, as the predominant species generated; DMSO was found to limit DNA oxidation-most likely through the trapping of hydroxyl radicals $\left[\left(\mathrm{CH}_{3}\right)_{2} \mathrm{SO}+{ }^{\bullet} \mathrm{OH} \rightarrow \mathrm{CH}_{3} \mathrm{SO}_{2} \mathrm{H}+\mathrm{CH}_{3}\right]$ (Burkitt and Mason, 1991) - with sodium azide $\left(\mathrm{NaN}_{3}\right)$ having neglibile influence on all complexes except $\mathrm{Cu}$-Terph. It is also likely that hydrogen peroxide $\left(\mathrm{H}_{2} \mathrm{O}_{2}\right)$ is the key intermediary in

\section{References}

Basu, A. K., Loechler, E. L., Leadon, S. A., and Essigmann, J. M. (1989). Genetic effects of thymine glycol: site-specific mutagenesis and molecular modeling studies. Proc. Natl. Acad. Sci. U.S.A. 86, 7677-7681. doi: 10.1073/pnas.86.20.7677

Breen, A. P., and Murphy, J. A. (1995). Reactions of oxyl radicals with DNA. Free Radic. Biol. Med. 18, 1033-1077. doi: 10.1016/0891-5849(94)00209-3

Burger, R. M. (1998). Cleavage of nucleic acids by Bleomycin. Chem. Rev. 98, 1153-1169. doi: 10.1021/cr960438a

Burger, R. M., Peisach, J., and Horwitz, S. B. (1981). Activated bleomycin. A transient complex of drug, iron, and oxygen that degrades DNA. J. Biol. Chem. 256, 11636-11644.

Burkitt, M. J., and Mason, R. P. (1991). Direct evidence for in vivo hydroxyl-radical generation in experimental iron overload: an ESR spin-trapping investigation. Proc. Natl. Acad. Sci. U.S.A. 88, 8440-8444. doi: 10.1073/pnas.88.19.8440

Chatgilialoglu, C., Ferreri, C., and Terzidis, M. A. (2011). Purine 5,8cyclonucleoside lesions: chemistry and biology. Chem. Soc. Rev. 40, 1368-1382. doi: $10.1039 / \mathrm{c} 0 \mathrm{cs} 00061 \mathrm{~b}$

Chatgilialoglu, C., and O'Neill, P. (2001). Free radicals associated with DNA damage. Exp. Gerontol. 36, 1459-1471. doi: 10.1016/S0531-5565(01)00132-2

Chen, J., Ghorai, M. K., Kenney, G., and Stubbe, J. (2008). Mechanistic studies on bleomycin-mediated DNA damage: multiple binding modes can result in double-stranded DNA cleavage. Nucleic Acids Res. 36, 3781-3790. doi: 10.1093/nar/gkn302

Cooke, M. S., and Evans, M. D. (2007). 8-Oxo-deoxyguanosine: reduce, reuse, recycle? Proc. Natl. Acad. Sci. U.S.A. 104, 13535-13536. doi: 10.1073/pnas.0706878104

Dunand, C., Crèvecoeur, M., and Penel, C. (2007). Distribution of superoxide and hydrogen peroxide in Arabidopsis root and their influence on root development: possible interaction with peroxidases. New Phytol. 174, 332-341. doi: 10.1111/j.1469-8137.2007.01995.x
- $\mathrm{OH}$ production as the peroxide scavenger KI (Dunand et al., 2007; Steffens et al., 2012) was refractory to oxidative damage by tested agents. The generation of hydroxyl-based radicals was corroborated through identification of 8-oxo- $2^{\prime}$-deoxyguanosine (8-oxo-dG) DNA lesions quantified under an ELISA protocol. 8-oxo-dG liberation followed the overall trend Cu-DPQ-Phen > $\mathrm{Cu}$-Terph $>\mathrm{Cu}$-Phen $>\mathrm{Cu}$-DPPZ with higher lesion numbers detected under heavily sheared (damaged) plasmid conditions. Finally, oxidative damage by the complex series was found to inhibit the DNA replication process; polymerase chain reaction (PRC) reactions were impeded-particularly along A-T rich chains-through oxidative damage of template strands with the di-nuclear $\mathrm{Cu}$-Terph, and mono-nuclear $\mathrm{Cu}-\mathrm{DPQ}-\mathrm{Phen}$, being particularly potent oxidants to this process.

\section{Acknowledgments}

This work was supported by Irish Research Council (IRC) grants GOIPG/2013/826 and GOIPG/2014/1182. Sponsorship from COST Action CM1201: "Biomimetic Radical Chemistry" is gratefully acknowledged.

\section{Supplementary Material}

The Supplementary Material for this article can be found online at: http://journal.frontiersin.org/article/10.3389/fchem. 2015.00028/abstract

Franco, R., Panayiotidis, M. I., and Cidlowski, J. A. (2007). Glutathione depletion Is necessary for apoptosis in lymphoid cells independent of reactive oxygen species formation. J. Biol. Chem. 282, 30452-30465. doi: 10.1074/jbc.M703091200

Gajewski, E., Aruoma, O. I., Dizdaroglu, M., and Halliwell, B. (1991). Bleomycindependent damage to the bases in DNA is a minor side reaction. Biochemistry 30, 2444-2448. doi: 10.1021/bi00223a021

Johnson, G. R. A., and Nazhat, N. B. (1987). Kinetics and mechanism of the reaction of the bis(1,10-phenanthroline)copper(I) ion with hydrogen peroxide in aqueous solution. J. Am. Chem. Soc. 109, 1990-1994. doi: 10.1021/ja002 $41 \mathrm{a} 015$

Kellett, A., Howe, O., O'Connor, M., McCann, M., Creaven, B. S., McClean, S., et al. (2012). Radical-induced DNA damage by cytotoxic square-planar copper(II) complexes incorporating o-phthalate and 1,10phenanthroline or 2,2'-dipyridyl. Free Radic. Biol. Med. 53, 564-576. doi: 10.1016/j.freeradbiomed.2012.05.034

Kellett, A., O’Connor, M., McCann, M., McNamara, M., Lynch, P., Rosair, G., et al. (2011). Bis-phenanthroline copper(II) phthalate complexes are potent in vitro antitumour agents with "self-activating" metallo-nuclease and DNA binding properties. Dalton Trans. 40, 1024-1027. doi: 10.1039/c0dt 01607a

Klaunig, J. E., Kamendulis, L. M., and Hocevar, B. A. (2010). Oxidative stress and oxidative damage in carcinogenesis. Toxicol. Pathol. 38, 96-109. doi: $10.1177 / 0192623309356453$

Li, L., Karlin, K. D., and Rokita, S. E. (2005). Changing selectivity of DNA oxidation from deoxyribose to guanine by ligand design and a new binuclear copper complex. J. Am. Chem. Soc. 127, 520-521. doi: 10.1021/ja04 $4209 \mathrm{e}$

Marshall, L. E., Graham, D. R., Reich, K. A., and Sigman, D. S. (1981). Cleavage of deoxyribonucleic acid by the 1,10-phenanthroline-cuprous complex. Hydrogen peroxide requirement and primary and secondary structure specificity. Biochemistry 20, 244-250. doi: 10.1021/bi00505a003 
Mazzer, P. A., Maurmann, L., and Bose, R. N. (2007). Mechanisms of DNA damage and insight into mutations by chromium(VI) in the presence of glutathione. J. Inorg. Biochem. 101, 44-55. doi: 10.1016/j.jinorgbio.2006.08.008

McCann, M., McGinley, J., Ni, K., O’Connor, M., Kavanagh, K., McKee, V., et al. (2013). A new phenanthroline-oxazine ligand: synthesis, coordination chemistry and atypical DNA binding interaction. Chem. Comm. 49, 2341-2343. doi: $10.1039 / \mathrm{c} 3 \mathrm{cc} 38710 \mathrm{k}$

Merkel, P. B., Nilsson, R., and Kearns, D. R. (1972). Deuterium effects on singlet oxygen lifetimes in solutions. New test of singlet oxygen reactions. J. Am. Chem. Soc. 94, 1030-1031. doi: 10.1021/ja00758a072

Molphy, Z., Prisecaru, A., Slator, C., Barron, N., McCann, M., Colleran, J., et al. (2014). Copper phenanthrene oxidative chemical nucleases. Inorg. Chem. 53, 5392-5404. doi: 10.1021/ic500914j

Natrajan, A., Hecht, S. M., and van der Marel, G. A. (1990). A study of oxygenversus hydrogen peroxide-supported activation of iron. cntdot. bleomycin. J. Am. Chem. Soc. 112, 3997-4002. doi: 10.1021/ja00166a042

Pratviel, G., and Bernadou, J. (1989). Evidence for high-valent iron-oxo species active in the DNA breaks mediated by iron-bleomycin. Biochem. Pharmacol. 38, 133-140. doi: 10.1016/0006-2952(89)90159-7

Prisecaru, A., Devereux, M., Barron, N., McCann, M., Colleran, J., Casey, A., et al. (2012). Potent oxidative DNA cleavage by the di-copper cytotoxin: $\left[\mathrm{Cu}_{2}(\mu \text {-terephthalate })(1,10 \text {-phen })_{4}\right]^{2+}$. Chem. Commun. 48, 6906-6908. doi: $10.1039 / \mathrm{c} 2 \mathrm{cc} 31023 \mathrm{f}$

Prisecaru, A., McKee, V., Howe, O., Rochford, G., McCann, M., Colleran, J., et al. (2013). Regulating Bioactivity of Cu2 + Bis-1,10-phenanthroline Artificial Metallonucleases with Sterically Functionalized Pendant Carboxylates. J. Med. Chem. 56, 8599-8615. doi: 10.1021/jm401465m

Rodriguez, L. O., and Hecht, S. M. (1982). Iron(II)-bleomycin. Biochemical and spectral properties in the presence of radical scavengers. Biochem. Biophys. Res. Commun. 164, 1470-1476. doi: 10.1016/0006-291X(82)91416-4

Sanchez-Cano, C., Huxley, M., Ducani, C., Hamad, A. E., Browning, M. J., Navarro-Ranninger, C., et al. (2010). Conjugation of testosterone modifies the interaction of mono-functional cationic platinum(II) complexes with DNA, causing significant alterations to the DNA helix. Dalton Trans. 39, 11365-11374. doi: 10.1039/c0dt00839g

Sigman, D. S., Graham, D. R., Aurora, V. D., and Stern, A. M. (1979). Oxygendependent cleavage of DNA by the 1,10-phenathroline cuporous complex. Inhibition of Escherichia coli DNA polymerase I. J. Biol. Chem. 254, 12269-12272.
Steffens, B., Kovalev, A., Gorb, S. N., and Sauter, M. (2012). Emerging roots alter epidermal cell fate through mechanical and reactive oxygen species signaling. Plant Cell 24, 3296-3306. doi: 10.1105/tpc.112.101790

Stubbe, J. A., and Kozarich, J. W. (1987). Mechanisms of bleomycin-induced DNA degradation. Chem. Rev. 87, 1107-1136. doi: 10.1021/cr00081a011

Tabassum, S., Al-Asbahy, W. M., Afzal, M., Arjmand, F., and Bagchi, V. (2012). Molecular drug design, synthesis and structure elucidation of a new specific target peptide based metallo drug for cancer chemotherapy as topoisomerase I inhibitor. Dalton Trans. 41, 4955-4964. doi: 10.1039/c2dt $12044 \mathrm{e}$

van der Steen, S., de Hoog, P., van der Schilden, K., Gamez, P., Pitié, M., Kiss, R., et al. (2010). Novel heteronuclear ruthenium-copper coordination compounds as efficient DNA-cleaving agents. Chem. Commun. 46, 3568. doi: $10.1039 / \mathrm{c} 000077 \mathrm{a}$

Xia, Q., Chou, M. W., Yin, J. J., Howard, P. C., Yu, H., and Fu, P. P. (2006). Photoirradiation of representative polycyclic aromatic hydrocarbons and twelve isomeric methylbenz $[\alpha]$ anthracene with UVA light: formation of lipid peroxidation. Toxicol. Ind. Health 22, 147-156. doi: 10.1191/0748233706 th259oa

Xu, M., Lai, Y., Jiang, Z., Terzidis, M. A., Masi, A., Chatgilialoglu, C., et al. (2014). A 5', 8-cyclo-2'-deoxypurine lesion induces trinucleotide repeat deletion via a unique lesion bypass by DNA polymerase $\beta$. Nucleic Acids Res. 42, 13749-13763. doi: 10.1093/nar/gku1239

Zhou, W., Wang, X., Hu, M., Zhu, C., and Guo, Z. (2014). A mitochondriontargeting copper complex exhibits potent cytotoxicity against cisplatin-resistant tumor cells through multiple mechanisms of action. Chem. Sci. 5, 2761-2770. doi: $10.1039 / \mathrm{c} 4 \mathrm{sc} 00384 \mathrm{e}$

Conflict of Interest Statement: The authors declare that the research was conducted in the absence of any commercial or financial relationships that could be construed as a potential conflict of interest.

Copyright (c) 2015 Molphy, Slator, Chatgilialoglu and Kellett. This is an open-access article distributed under the terms of the Creative Commons Attribution License (CC $B Y)$. The use, distribution or reproduction in other forums is permitted, provided the original author(s) or licensor are credited and that the original publication in this journal is cited, in accordance with accepted academic practice. No use, distribution or reproduction is permitted which does not comply with these terms. 